\title{
CERTAIN NURSERIES OF INSECT LIFE IN WEST AFRICA.
}

\author{
By J. W. S. Macfie and A. Ingram.
}

When studying the bionomics of certain species of the CERATOPOGONINAE in the Gold Coast, samples of material collected from different sources, where it seemed likely that the early stages of these small insects might be passed, were brought to the laboratory for examination. The samples were chiefly taken from rot-holes in live trees, from cut bamboo stumps, from decaying logs, from old canoes, from the edges of pools and puddles, from crab-holes, and from the bases of banana plants.

Each sample on arrival was placed in a wide-mouthed glass jar, and-the mouth of the jar having been covered with a glass plate-was kept under observation for at least seven days, after which period, if no insect had hatched and no larva or pupa had been seen, it was thrown away. Experience having proved that dry samples were unproductive of insects, and that complete submergence of the material in water drowned certain larvae, it was found necessary to arrange the samples in the jars in such a way that they were damp but did not become water-logged. This was effected by pouring water into the jars to a depth of a quarter to half an inch, and by heaping up the material at one side ; in this way it was possible to rear terrestrial and aquatic larvae simultaneously. Many of the samples proved barren ; on the other hand, those from certain sources were found to be teeming with insect life. The most productive material examined was banana fibre in a state of decomposition, such as can readily be found at the base of most mature banana plants; the fibre must be of a brown hue and somewhat softened, hard cream-coloured fibre having been found to yield so few insects as scarcely to be worth the trouble of collection. How prolific of insect life such decaying banana fibre can be, may be judged from the fact that over a hundred specimens of CERATOPOGONINAE alone, comprising at least five species, were obtained from a single sample of this material, which weighed about $1 \frac{1}{2} \mathrm{lb}$., in the course of five weeks during which it was under observation. Next in productiveness to banana fibre were the debris collected from rot-holes in live trees and the rotting wood scraped from the ends and sides of old canoes tied to the bank of the river Densu at a village called Oblogo.

As such samples yielded not only CERATOPOGONINAE, but also other insects, it may be of interest to give lists of the insects which hatched from them, merely as a suggestion of the wonderful assemblage of insect life which may be found in small quantities of decaying vegetable matter in West Africa. It is to be noted that banana fibre and the rotting wood at the sides and ends of canoes are normally habitats of terrestrial larvae, though occasionally they may become suitable for aquatic larvae, as, for example, when the stem of a banana plant has been cut through and the hollow becomes filled with water, or when a canoe becomes filled with rain-water. 


\section{Decaying Banana Fibre.}

The following mosquitos and Ceratopogonine midges were reared from decaying banana fibre :-

Mosourtos.

Culex (Culiciomyia) nebulosus, Theo. Eretmopodites chrysogaster, Graham. Aeddes (Ochlerotatus) apicoannulatus, Theo.

Aëdes (Stegomyia) dendrophilus, Edw.
Ceratopogonine Midges.

Culicoides austeni, C. I. \& M.

C. eriodendroni, C. I. \& M.

C. grahami, Aust.

C. inornatipennis, C. I. \& M.

C. inornatipennis, C. I. \& M., var. rutilus, I. \& M.

Dasyhelea flava, C. I. \& M.

D. fusciscutellata, C. I. \& M.

D. luteoscutellata, C. I. \& M.

D. pallidihalter, C. I. \& M.

D. similis, C. I. \& M.

Forcipomvia castanea, Walk.

$F$. ingrami, Cart.

Forcipomyia sp. n.

In addition to these insects two species of PSychodidar, Telmatoscopus meridionalis, Eaton, and a small unidentified species, were reared from the same material, one species of PODURIDAE, and two species of MUSCOIDEA, one apparently a "fruit-fly." Species of the genera Styringomyia, Olbiogaster, and Mesochria were also reared from rotting banana fibre.

\section{Rotting Wood from Old Canoos.}

The following mosquitos and Ceratopogonine midges were reared from rotting wood taken from the ends and sides of old canoes tied to the bank of the river Densu at Oblogo, a village near Accra :-

\section{Mosquitos.}

Anopheles costalis, Lw.

Aëdes argenteus, Poir. (Stegomyia fasciata, F.).

Culex decens, Theo.

Lutzia tigripes, Grp., var. fusca, Theo.
Ceratopogonine Midges.

Atrichopogon chrysosphaerotum, I. \& M. A. homoium, I. \& M.

Culicoides schultzei, End.

C. similis, C. I. \& M.

Dasyhelea flaviformis, C. I. \& M.

D. fusca, C. I. \& M.

D. inconspicuosa, C. I. \& M.

Thysanognathus (Prionognathus) pseudomaculipennis, C. I. \& M.

Probezzia pistiae, I. \& M.

Stilobezzia spirogyrae, C. I. \& M.

In addition, at least two small species of CHIRonomidaE were reared from this material.

\section{Rot-holes in Living Trees.}

Rot-holes in trees are a most prolific source of mosquitos, and for this reason have attracted the attention of sanitarians ; they are equally objectionable as a source of biting midges and other insects. From material taken at various times from a single 
rot-hole in a particular silk-cotton tree (Eriodendron anfractuosum) at Nsawam the following mosquitos and Ceratopogonine midges were reared :-

\section{MosQuiros.}

Culex (Culiciomyia) nebulosus, Theo. Aèdes (S.) apicoargenteus, Theo.

A. (S.) dendrophilus, Edw.

$A$. (S.) argenteus, Poir.

A. (S.) luteocephalus, Newst.

A. (O.) apicoannulatus, Edw.

Toxorhynchites brevipalpis, Theo.

\section{Ceratopogonine Midges.}

Culicoides accraensis, C. I. \& M.

C. clarkei, C. I. \& M.

C. confusus, C. I. \& M.

C. eriodendroni, C. I. \& M.

C. inornatipennis, C. I. \& M.

C. inornatipennis, C. I. \& M., var. rutilus, I. \& M.

C. punctithorax, C. I. \& M.

Forcipomyia ingrami, Cart.

In addition, two species of PSYCHODIDAE, Telmatoscopus meridionalis and a small species not yet identified, were reared from material from this particular rot-hole, one large species of CHIRONOMIDAE, and two species of TIPUlIDAE; a species of cockroach was also found to inhabit this rot-hole.

The larvae of Anopheles costalis, Loew, although not found in this particular tree are found occasionally in rot-holes in trees at Accra.

Larvae of Stegomyia are especially associated with rot-holes in trees. In a flamboyant tree (Poinciana regia) in the laboratory compound there is a rot-hole which is permitted to remain untouched by the sanitary authorities on condition that we keep close watch over it. From this rot-hole we have obtained Aëdes (Stegomyia) apicoargenteus, Theo., Aëdes argenteus, Poir. (S. fasciata, F.), Aëdes (S.) luteocephalus, Newst., Aëdes (S.) metallicus, Edw., Aëdes (S.) simpsoni, Theo., and Aëdes (S.) unilineatus, Theo.--that is, all the species of the subgenus Stegomyia known to occur in Accra.

It would perhaps be more accurate to describe the larvae of this subgenus as frequenting small enclosed collections of water, since they are by no means restricted to rot-holes in trees. Aëdes argenteus (Stegomyia fasciata), indeed, appears to have become largely a domestic mosquito, laying its eggs in the vessels which accumulate in the vicinity of human habitations. Far from the haunts of man, however, larvae of this species are abundant not only in rot-holes, but also in old calabashes, small rock pools, and similar situations, so that it may well be that its domestic habit is less an adaptation than an accidental occurrence, the result of the great multiplication in and around towns and villages (especially those to which European civilisation has introduced the tin) of just those kinds of situation which the mosquito was accustomed to select as favourable for the development of its larvae, and which, moreover, have the additional advantage that they are not frequented by its natural enemies. Other species appear to be more particular as to the nature of their nurseries, for example, Aedes $(S$.) vittatus shows a strong preference for rock pools, and we have not found $A$. (S.) metallicus and $A$. (S.) unilineatus except in rot-holes in trees. As has been suggested by one of us (Report of the Accra Laboratory for the year 1916, pp. 28-29), the resistant eggs of Stegomyia (and such resistant eggs are not peculiar to Aeddes argenteus) are an adaptation not so much to the necessity of tiding over the dry season as to the habit of breeding in small enclosed collections of water, such as rotholes, which are apt to dry up between rain showers by evaporation or leakäge, leaving the eggs that had been deposited on the surface stranded on the sides. This adaptation not only saves the eggs from perishing, but also gives them a decided advantage over newly deposited eggs, for whereas eggs laid directly on the water take a few days (about three days in the case of Aedes argenteus) to hatch, those which have been stranded hatch immediately they are immersed-for instance, by a shower filling up the rot-hole-and the emerging larvae have therefore a better chance of completing their development before the rot-hole or other small collection of water dries up again. 
Associated with Pistia stratiotes.

It may be of interest to add here a short note on the insects we have found associated with the water lettuce, Pistia stratiotes, and to give the following list of mosquitos and Ceratopogonine midges which we have reared from plants of this weed taken, with a little of the surrounding water, from pools or river back-waters :-

Mosquitos.

Aeddes (Ochlerotatus) albocephalus, Theo. Aëdomyia africana, N.-L.

Anopheles costalis, Loew.

A. funestus, Giles.

A. mauritianus, Grp.

A. marshalli, Theo.

A. nili, Theo.

$A$. pharoensis, Theo.

Culex decens, Theo.

C. guiarti, Blanch.

C. (Micraëdes) inconspicuosus, Theo.

C. quasigelidus, Theo.

Lutzia tigripes, Grp., var. fusca, Theo.

Ficalbia mediolineata, Theo.

Mansonioides africanus, Theo.

Mimomyia mimomyiaformis, Newst.

$M$. splendens, Theo.

Uranotaenia balfouri, Theo.
Ceratopogonine Midges.

Atrichopogon ochrosoma, I. \& M.

Culicoides austeni, C. I. \& M.

C. distinctipennis, Aust.

Dasyhelea inconspicuosa, C. I. \& M.

Eukraiohelea africana, I. \& M.

E. versicolor, I. \& M.

Parabezzia poikiloptera, I. \& M.

Palpomyia pistiae, I. \& M.

Thysanognathus (Prionognathus)

pseudomaculipennis, C. I. \& M.

Probezzia pistiae, I. \& M.

$P$. stephensi, I. \& M.

Ankistrodactylus (Schizodactylus) par, I. \& M.

Sphaeromias litoraurea, I. \& M.

In addition to these insects several species of CHIRONOMIDAE were reared, and more than one species of SYRPHIDAE.

The list is a formidable one, and particular attention should be called to the fact that it includes six species of Anopheles-that is, all the species which are known to occur commonly in this part of the Gold Coast. The association of Anopheles with Pistia plants has previously been noted. On a former occasion (Bull. Ent. Res., viii, p. 136) we recorded that $A$. costalis, Loew, and $A$. marshalli, Theo., frequented Pistia-covered pools. In this connection, however, special mention should be made of the observations of Zetek (Bull. Ent. Res., xi, pp. 73-75), who has found $A$. albimanus, Wied., and $A$. tarsimaculatus, Goeldi, in association with this weed in the Panama Canal Zone, and has discussed the necessity of dealing with the plants. 